\title{
Faculty attitude and use of ICT in instructional delivery in tertiary institutions in a developing nation
}

Onwuagboke, Bede Blaise Chukwunyere $₫$

Alvan Ikoku Federal College of Education, Owerri, Nigeria (bbconwu@yahoo.com)

Singh, Termit Kaur Ranjit

Universiti Sains Malaysia, Malaysia (termitk@gmail.com)

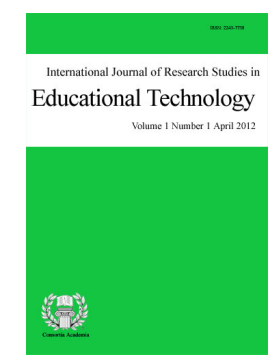

ISSN: $2243-7738$ Online ISSN: 2243-7746

OPEN ACCESS

\section{Abstract}

This study is a survey aimed at ascertaining the attitude of academic staff in tertiary institutions in Imo State Nigeria towards the use of information and communications technology (ICT) in teaching. It also examines their level of use of ICT for teaching and learning purposes. The paper also compares the attitude of the faculty by gender and type of the institution they teach in, i.e. college of education, polytechnic and universities. The paper tried to ascertain if attitude of faculty to ICT correlates to actual usage in the classroom. 300 academic staff members were randomly selected from lecturers in tertiary institutions in Nigeria. A set of instrument tagged ICT attitude questionnaire and ICT use questionnaire was administered to the respondents. Data collected was analysed using descriptive, inferential and correlational statistics. Findings reveal that although academic staff have positive attitude about ICT use in instruction, they however reported low level use of ICT for instructional purposes. There is no significant difference in attitude according to gender; similarly, significant differences in attitude does not exist by type of institution among the three types of tertiary institutions. Faculty attitude was found to be positively correlated with use of ICT in curriculum. The paper concludes that academic staff should embrace innovative techniques by a favourable disposition towards them which will help boost classroom implementation of such innovations.

Keywords: developing nation; faculty attitude; use of ICT; instruction; tertiary institutions 


\section{Faculty attitude and use of ICT in instructional delivery in tertiary institutions in a developing nation}

\section{Introduction}

Globalization has brought in its wake a lot of changes and innovations in the lives of people. The teaching of our young ones is an area of our lives that innovations in society have a very crucial role to play. One of the innovations which has impacted or at least has the potential of impacting on teaching and learning is the integration of ICT in Education. Evidence from researches abounds on the positive impact of ICT in teaching and learning outcomes of students (Higgins, 2003; Meijer et al., 2008; Ziden, Ismail, Spian, \& Kumutha, 2011). Many governments of nations have adopted the use of digital technology as a means of instructional delivery. However, it is worrisome that serious and sustained effort has not been made towards ensuring that it is fully integrated and internalised in a meaningful manner in educational institutions in developing countries. ICT has the capacity of democratizing access to education by delivering the learning content to many learners physically separated from each other in time and space (Oliver, 2006). Many developing nations are trying to fashion policies that mandates teachers to integrate ICT in their classrooms to catch up this trend so as not to be left at the other side of the digital divide.

Nigeria is a developing nation regarded as the most populous black nation in the world with a population of over 170 million people identified ICT as the bedrock for national survival and development (FRN, 2001). The country has 36 states and a federal capital territory Abuja. Imo State being one of the 36 states located in the south east geopolitical zone of the country lies within the area of high population density of the country. The state has 5 public tertiary institutions and recorded the highest enrolment in the unified tertiary institutions matriculation examination (UTME) in 2012 (Nnabugwu, 2012). Education is regarded as the largest industry in the state. For this industry to be productive and relevant in this knowledge era, it has to employ the current educational resources. ICT has come to be seen as necessary educational resource higher education should utilize in order to achieve educational goals in a digital era.

Many strategies are being used by management of many educational institutions to ensure that academic staff in their institutions uses ICT in their daily duties. One of such strategies as adopted by tertiary educational institutions in Nigeria is that all academic staff must be ICT literate before they are hired. Those already in service without ICT knowledge were given a mandate to update their knowledge through series of ICT capacity building workshops. One of the major determinants of ICT integration in the curriculum is teachers, attitude towards it (Hew \& Brush, 2007; Keengwe, Onchwari, \& Wachira, 2008). Many academic staff may not use technology in their teaching if they do not have positive attitude towards them. This implies that even after possessing basic ICT literacy through the capacity building workshops, faculty members who do not feel favourably disposed towards ICT may likely not utilize them in their teaching.

In view of the fact that Nigeria has stressed the importance of using of ICT in its education industry, especially at the tertiary level (FRN, 2008) given the enormous resources the government has spent on it through Nigeria Communication Commission (NCC) (Uka, 2014), it becomes pertinent to investigate the attitude towards ICT and actual use of ICT by faculty members. In doing so, this study posed and sought answers to the following questions in order to find out how ICT is being implemented in the curriculum in tertiary institutions in Imo State.

$>\quad$ What is the level of utilization of ICT for instructional purposes by faculty members?

$>\quad$ What is the attitude of faculty members towards the use of ICT for educational purposes?

$>\quad$ Is there any significant difference in attitudes of faculty members towards the use of ICT by gender 
Faculty attitude and use of ICT in instructional delivery in tertiary institutions in a developing nation and type of the institution?

$>\quad$ Is there a significant relationship between faculty members' level of ICT use in teaching and their attitudes towards ICT?

\section{Review of Related Literature}

\subsection{Need for ICT use in Instruction}

Scholars have canvassed the use of ICT in education for many benefits that it offers (Blamire \& Kefala, 2006; BECTA, 2008; Morgan, 1997; Ochoyi \& Ukwumonu, 2008; Pelgrum, 2001). This has driven the government of Nigeria to create an ICT policy in 2001 and state that ICT should be employed in instructional delivery at all levels of education (FRN, 2008). For this reason, every tertiary institution in Nigeria whether University, College of Education, Polytechnic or Monotechnic is expected to have a well-equipped and functional ICT centre for their programmes to pass accreditation by supervising bodies (NUC, NCCE, \& NBTE). The centres are to cater for ICT needs for instructional and administrational purposes. In addition, The Nigerian Communications Commission has continually helped in equipping the academic staff of these institutions through the donation of computers and other ICT resources (Uka, 2014).

Researchers have severally embarked on investigating the ICT usage for instructional purposes in the various levels of education. The results of their studies have shown mixed reports on ICT use at different levels. While some reported a high level use of ICT in instruction, (Okon \& Jacob, 2002; Bamigboye, Bankole, Ajibye \& George 2013) others, however, report low level usage (Akuegwu, Ntukidem, Ntukidem, \& Jaja, 2011; Al-Zaidiyeen, Mei, \& Fook, 2010; Aginam, 2006; Modebelu \& Azu 2014; Egomo, Enyi, \& Tah, 2012; Partnership for Higher Education in Africa, 2007). In most of the studies conducted it has been found that the attitude of the teacher to ICT to a very great extent is correlated to subsequent use of ICT in instruction.

\subsection{Teachers' attitude and ICT use in instruction}

There are many factors that can affect the use of ICT in the learning environment at any level of education. The teachers' attitude towards information and communication technology has been seen as a major factor. Evidence from research points to the fact that successful implementation of ICT in the curriculum depends largely on the attitude of teachers towards technology. Attitude is seen in psychology as an expression of favour or disfavour towards an attitude object, be it an event, person, place or thing. This attitude can be a positive or negative evaluation of people, objects, events, activities, and ideas. Attitude is a learned predisposition to react to an object or class of objects in a consistently favorable or unfavorable manner (Fishbein 1967). Researchers have been investigating teachers' attitude to ICT at various levels of education. Bamigboye, Bankole, Ajibye, and George (2013) discovered a positive attitude to ICT in a study they carried out among the academic staff of Federal University of Agriculture, Abeokuta Nigeria. Similarly, Al-Zaidiyeen, Mei, and Fook (2010) found that secondary school teachers in Jordanian schools who participated in their survey have a positive attitude towards ICT utilization in the classroom.

In a different but related study, Yusuf and Balogun (2011) found a positive attitude towards ICT among pre-service teachers in a Nigerian University. In the same vein, Dogan (2010) in a study of Primary trainee teachers' attitudes towards ICT and use of ICT in mathematics in Turkey found a similar result. Albirini (2004) carried out a study to ascertain the attitudes of EFL teachers in Syrian high schools toward ICT in the curriculum. The result shows that teachers had positive attitudes toward ICT use in the curriculum. In all the studies cited above, there has been a consistent report of positive attitude towards ICT in the curriculum. The motivational attribute of ICT and the emphasis various governments of nations placed on its' use in education may have been responsible for this favourable disposition towards it. 


\subsection{Gender and attitude towards ICT use in the learning environment}

Gender is a factor that has played a role in how people react to or perceive a phenomenon in any setting. Traditional African societies tend to create barriers to female optimum achievement in society to the effect that females tend to have a lower social position and fewer opportunities than males. Naturally, females have more responsibilities in reproductive and household tasks with the resultant effect that females in general have less access to power, education and productive sources than males (McGregor \& Bazi, 2001). Researchers over the years have investigated the impact of gender on ICT attitude. Ainley and Enger (2007) reported that males are more positive in their attitudes toward ICT than females. Papaioannou and Charalambous (2011) investigated the impact of gender on the attitudes toward ICT. They concluded that both male and female have positive attitudes toward ICT; however, they reported males having stronger positive attitudes than their female counterparts. Other researchers have found no significant difference in attitude towards ICT by gender (Intaganok, Waterworth, Andsavachulamanee, Grasaresom, \& Homkome, 2008; Elsadaani 2012; Omollo, Indoshi, \& Ayere, 2013). With these conflicting findings, it becomes necessary to investigate this phenomenon further. This is predicated on the fact that there is an apparent paucity of research on attitude of lecturers towards ICT use in relation to gender in Imo state tertiary institutions.

\subsection{Relationship between attitude and ICT use in instruction}

A person's attitude towards an object, place or event to a very great extent determines his or her behaviour towards it. In the case of using ICT in the classroom, a faculty who has a negative disposition towards ICT will most often not use it in teaching. Researches carried out in search of correlation between attitude of teachers and their ICT use that point in this direction abound (Al-Zaidiyeen, Mei, \& Fook 2010; Albrini, 2006; Sang, Valcke, van Braak, \& Tondeur, 2010). In the case of the study carried out in Jordanian secondary schools, Al-Zaidiyeen, Mei, and Fook (2010) found a significant positive correlation between teachers' attitudes towards ICT and their level of ICT use in instruction. Attitude of the teacher plays a vital role and is a predictor of innovative use of technology in the curriculum (Albrini, 2006). It has been stressed in some other studies that a strong relationship exists between attitudes towards ICT and use of ICT in education (van Braak et al., 2004; Sang et al., 2010). According to Huang and Liaw (2005) a teacher's attitude to ICT not only affects his or her acceptance of technology in the classroom but also determines integration of same in teaching.

\section{Materials and Methods}

The study was conducted using a quantitative research paradigm using a descriptive survey design which was aimed at finding out the attitude of academic staff in tertiary institutions in Imo state Nigeria towards ICT use in teaching and learning. A sample of 300 respondents was drawn from the entire faculty members of the tertiary institutions in Imo State using a stratified random sampling technique. Thus, 60 respondents were selected from each of the 5 tertiary institutions in the state. In each of the institutions, 10 respondents were drawn from each of the randomly selected 6 schools/faculties. Ten respondents from each school/faculty were selected from the faculty list by balloting.

Two sets of instruments were used to collect data from the respondents. They are computer attitude questionnaire and ICT use questionnaire which are 4-point Likert scale items which requires the respondents to choose from Strongly Agree, Agree, Disagree and Strongly Disagree to express their feeling about statements concerning ICT and its usage in their teaching. The ICT attitude questionnaire (ICTAQ) is made up of 15 items adapted from ICT questionnaire developed by Albirini (2006). The scale comprises of a15-item 4-point Likert scale. The ICT use questionnaire (ICTUQ) comprises of an 18-item scale which seek, to find the frequency of use of ICT by faculty members in their teaching. A panel of 3 experts in educational technology was used to validate the ICTUQ instrument in terms of content, clarity and use of language. The instruments were pilot tested in a tertiary institution in a neighbouring state to establish its reliability through test retest method. The reliability coefficient of the ICTAQ was .81 Cronbach's alpha while that of the ICTAQ was .78 Cronbach's alpha. 


\subsection{Data Analysis}

A total of 243 questionnaires were properly filled out and returned hence the data analysis was based on them. In scoring the items in the ICTAQ, strongly agree was scored 4; agree 3; disagree 2 and strongly disagree 1 for positive items. Negative items on the hand were reversed thus strongly agree was scored 1; agree scored 2; disagree scored 3 and strongly disagree scored 4. The total score gives the faculty member's score on ICT attitude. In the case of ICTUQ, Never was scored 1, Rarely scored 2, Sometimes scored 3, Often scored 4 and Very often scored 5. In analysing the data collected from the study, descriptive statistics were used to ascertain the attitude of the faculty members towards ICT use in instruction while inferential statistics were used to compare the attitude of various groups in the sample. Pearson's correlation was used to find the correlation between their attitude to ICT and their utilization of same in their teaching.

\subsection{Demographic Information of Respondents}

The respondents to the research instrument comprise of 243 academic staff from the five tertiary institutions in Imo State. Data presented in table 1 show that 132 of them are males representing 54.3\% whereas 111 are females representing $45.7 \%$ of the respondents. Furthermore 50 of them teach in college of education representing $20.6 \%$, 85 teach in polytechnics representing $35 \%$, while the remaining 108 teach in universities representing $44.4 \%$.

\section{Table 1}

Description of respondents by gender and type of institution

\begin{tabular}{llccccc}
\hline & & \multicolumn{2}{c}{ Gender } & & \\
\cline { 3 - 4 } & & male & Female & & Total & $\%$ \\
\hline Institution type & College of Education & 19 & 31 & 50 & 20.6 \\
& Polytechnic & 42 & 43 & 85 & 35 \\
& University & 71 & 37 & 108 & 44.4 \\
Total & & 132 & 111 & 243 & 100 \\
\hline
\end{tabular}

\section{Results}

The result of the study shows that the level of utilization of ICT in instruction in the tertiary institutions in Imo state is low. The mean response for each of the items in the research instrument as shown in table 2 indicate that only 6 items out of 18 items on the scale received responses indicating above average use in instruction (Finding information and resources on the internet $\mathrm{M}=3.268$; $\mathrm{SD}=.961$, Developing teaching materials $\mathrm{M}=3.169 ; \mathrm{SD}=.755$, Typing test and examination papers $\mathrm{M}=2.971 ; \mathrm{SD}=1.069$, Publishing students results $\mathrm{M}=$ 2.93; $\mathrm{SD}=.765$, Research lesson background information on the Internet $\mathrm{M}=3.276 ; \mathrm{SD}=.989$ ). The remaining 12 items received responses which are below average signifying low use of ICT for instructional purpose. The grand mean of 2.19 further shows this low ICT utilization in instruction by faculty members in these institutions.

Table 2

Mean and Standard deviation of ICT use in teaching and learning $(N=243)$

\begin{tabular}{lcc}
\hline \multicolumn{1}{c}{ ICT use in teaching and learning } & Mean & SD \\
\hline Use ICT for College/faculty administration & 1.8272 & .75717 \\
Recording marks and using spreadsheet & 2.2963 & .92858 \\
Typing test items and exam papers & 2.9712 & 1.06948 \\
Finding information and resources on the internet & 3.2675 & .96126 \\
Developing teaching materials & 3.1687 & .75537 \\
Publishing students' result & 2.9300 & .76550 \\
\hline
\end{tabular}


Table 2 ... continued

\begin{tabular}{lcc}
\hline ICT use in teaching and learning & Mean & SD \\
\hline Word processing & 2.4691 & .73439 \\
Presentations (Power Point) & 2.4444 & .74412 \\
E-mail & 1.8642 & .74556 \\
Social networking & 1.8395 & .70635 \\
Internet browsing & 2.8683 & .75456 \\
Preparing CD ROM \& DVD for individualized learning & 1.8066 & .70391 \\
Encourage students to communicate with peers and lecturers via e-mail and instant & 1.7942 & .64190 \\
messages & 1.4198 & .58629 \\
Drill and practice using computers & 3.2757 & .98863 \\
Research lesson background information on the Internet & 1.7984 & .70746 \\
Use social network platforms to communicate and interact on educational matters & 1.5638 & .58832 \\
Produce projects/assignments using office suite programs & 1.6173 & .60783 \\
Solving problems, making decisions or forming opinions & Grand Mean & 2.19 \\
\hline
\end{tabular}

On the attitude of the academic staff towards ICT, the result presented in table 3 shows that the respondents seem to have a positive attitude towards ICT. All items on the scale received mean responses that are above average. The item that received the lowest mean score is Computers can enhance students' learning $(\mathrm{M}=2.9177$; $\mathrm{SD}=.84392$ ). The grand mean of 3.08 further shows this positive attitude towards ICT in the learning situation.

Table 3

Mean and Standard deviation of Attitude towards ICT in education $(N=243)$

\begin{tabular}{lcc}
\hline \multicolumn{1}{c}{ Feelings about ICT in teaching and learning } & Mean & SD \\
\hline Computers would help me organise my work & 3.0947 & .77359 \\
Computers make subject matter more interesting & 3.0617 & .79272 \\
Computers save time and effort & 3.1399 & .76397 \\
Using computers is very enjoyable & 3.0453 & .76737 \\
Computers makes me much more productive & 3.0412 & .80696 \\
Teaching with computers offers real advantages & 3.0617 & .69256 \\
Computers have proved to be effective learning tools & 3.2346 & .75413 \\
Computers can enhance students' learning & 2.9177 & .84392 \\
Computers will improve education & 3.0617 & .79272 \\
Computers do not scare me at all & 3.1811 & .68040 \\
I do not like talking with others about computers & 3.1646 & .66623 \\
I would rather do things by hand than with a computer & 3.0370 & .75697 \\
I like to use computers in teaching & 3.0123 & .78457 \\
Computers are a fast means of getting information & 3.0988 & .68523 \\
I would like to learn more about computers & 3.0905 & .84796 \\
\end{tabular}

The result displayed in table 4 shows that there are differences in the mean scores between male $(\mathrm{M}=44.9545, \mathrm{SD}=4.14041)$ and female $(\mathrm{M}=44.1532, \mathrm{SD}=3.87345)$ faculty members. The mean scores of males were slightly above that of the females. While, an independent samples test of mean difference was run to determine if the observed difference is statistically significant. The result of the test is as displayed in table 5 . The table indicates that there is no statistically significant difference in the mean scores of male ( $M=44.9545$, $\mathrm{SD}=4.14041)$ and female $(\mathrm{M}=44.1532, \mathrm{SD}=3.87345, \mathrm{t}(241)=1.548, \mathrm{p}=.123$ two-tailed $)$ faculty members in attitude towards ICT. The magnitude of the difference in the means (mean difference $=.80139,95 \%$ CI: -.21860 
to 1.82138$)$ was rather very small.

\section{Table 4}

Means for ICT Attitude of male and female faculty members

\begin{tabular}{llcccc}
\hline & Gender & $\mathrm{N}$ & Mean & Std. Deviation & Std. Error Mean \\
\hline TFICTAA & male & 132 & 44.9545 & 4.14041 & .36038 \\
& Female & 111 & 44.1532 & 3.87345 & .36765 \\
\hline
\end{tabular}

Table 5

Independent Samples T-test of male and female faculty members on ICT attitude

\begin{tabular}{lccccc}
\hline & $\mathrm{t}$ & $\mathrm{df}$ & Sig.(2-tailed) & $\begin{array}{c}\text { Mean } \\
\text { Difference }\end{array}$ & $\begin{array}{c}\text { Std. Error } \\
\text { Difference }\end{array}$ \\
\hline ICT Attitude & 1.548 & 241 & .123 & .80139 & .51780 \\
\hline
\end{tabular}

Similarly, to determine if differences exist in attitude to ICT between faculty members in Colleges of Education, Polytechnics and Universities, a table of means of the three groups is hereby presented. The mean scores on ICT attitude for the only College of Education is $(\mathrm{M}=46.6800, \mathrm{SD}=3.95609)$, the Polytechnics is $(\mathrm{M}=46.4824, \mathrm{SD}=4.20207)$ and Universities is $(\mathrm{M}=47.0370, \mathrm{SD}=4.66429)$ as shown in table 6.

Table 6

Means for Faculty members on Attitude towards ICT by type of Institution

\begin{tabular}{lccc}
\hline \multicolumn{1}{c}{ Institution type } & Mean & $\mathrm{N}$ & Std. Deviation \\
\hline College of Education & 46.6800 & 50 & 3.95609 \\
Polytechnic & 46.4824 & 85 & 4.20207 \\
University & 47.0370 & 108 & 4.66429 \\
Total & 46.7695 & 243 & 4.35657 \\
\hline
\end{tabular}

From the table, it can be seen that there is a difference in the mean scores of three groups with the universities having the highest mean scores followed by college of education and polytechnics. To determine if the observed differences is statistically significant, a one way Analysis of variance (ANOVA) test was performed. Table 7 shows that there is no significant difference at the $p<.05$ in the attitude towards ICT use in education for the three groups based on the type of institution: $\mathrm{F}(2,240)=.397, p=.673$. Based on this finding it was concluded that there is no significant difference in attitude towards ICT between the three groups of faculty members.

\section{Table 7}

ANOVA table of mean scores of the three groups

\begin{tabular}{lccccc}
\hline & $\begin{array}{c}\text { Sum of } \\
\text { Squares }\end{array}$ & df & Mean Square & F & Sig. \\
\hline Between Groups & 15.139 & 2 & 7.570 & .397 & .673 \\
Within Groups & 4577.955 & 240 & 19.075 & & \\
Total & 4593.095 & 242 & & & \\
\hline
\end{tabular}

Pearson's correlation was used to test if there is a relationship between the faculty members' attitude to ICT and their use of ICT for instructional purposes. The result reveals a positive correlation. Table 8 indicates that a positive relationship was established between the level of ICT utilization for instructional purposes and faculty's attitudes towards the use of ICT. 
Onwuagboke, B. B. C., \& Singh, T. K. R.

Table 8

Pearson's correlation between faculty ICT Attitude and ICT use in instruction

\begin{tabular}{llcc}
\hline & & ICT Attitude & $\begin{array}{c}\text { ICT Use in } \\
\text { Instruction }\end{array}$ \\
\hline ICT Attitude & Pearson Correlation & 1 & $.212^{* *}$ \\
& Sig. (2-tailed) & & .001 \\
\hline ICT Use in Instruction & Pearson Correlation & $.212^{* *}$ & 1 \\
& Sig. (2-tailed) & .001 & \\
\hline
\end{tabular}

Note. $* *$ Correlation is significant at the 0.01 level (2-tailed)

The results revealed that, there was a significant relationship $(\mathrm{r}=0.212 ; p<0.01)$ between the level of ICT use for educational purposes and teachers' attitudes towards the use of ICT, which showed that the more the faculty members of tertiary institutions have positive attitudes towards the use of ICT for instructional purposes, the more they used ICT for instructional reasons.

\section{Discussion}

\subsection{Discussion of findings}

The findings show that the level of ICT utilization in instruction in these institutions is still at a low level. This is in tandem with (Akuegwu, Ntukidem, Ntukidem, \& Jaja, 2011; Al-Zaidiyeen, Mei, \& Fook, 2010; Aginam, 2006; Modebelu \& Azu, 2014; Egomo, Enyi, \& Tah, 2012; Partnership for Higher Education in Africa, 2007) and at variance with (Okon \& Jacob, 2002; Bamigboye, Bankole, Ajibye, \& George 2013). This low level utilization of ICT in instruction as revealed by the findings may not be unconnected to the low level availability of ICT resources and other challenges to ICT in instruction as reported by researchers (Archibong, Ogbiji, \& Anijaobi-Idem, 2010; Modebelu \& Azu 2014; Onwuagboke, Singh, \& Onwuagboke, 2014; Ume \& Okonkwo 2014). A faculty member cannot make use of resources that are not available for integration in the learning environment. Even where the resources are available, the challenges of inadequate electricity may hinder their use in teaching. With these prevailing challenges, high level use of ICT in the curriculum may not be achieved.

The result also shows that faculty members in the tertiary institutions in Imo State have a positive attitude towards the use of ICT in teaching and learning. This finding is supported by the findings of Bamigboye et al., (2013), who reported that lecturers in a Nigerian university have a favourable attitude towards the use of ICT in education. In the same vein, Al-Zaidiyeen, Mei, and Fook (2010) reported a similar finding among secondary school teachers in Jordan while Yusuf and Balogun (2011) reported a positive attitude towards ICT among pre-service teachers in another Nigerian university. As many of the lecturers have at one time or the other been exposed to capacity building workshops relating to ICT, the positive attitude to ICT can be explained. They have come to realise the place of ICT in the $21^{\text {st }}$ century classroom and are ready to implement same if the enabling environment is provided.

Gender was found to have no significant effect on ICT attitude of faculty members. By implication, both male and female academic staff in the tertiary institutions in the state equally exhibits a positive attitude to the use of ICT in teaching and learning. This finding is in tandem with the findings of Elsadaani (2012) which reported no significant difference in ICT attitude by gender among Egyptian higher education academic staff. Omollo, Indoshi, and Ayere (2013) also reported no significant difference in ICT attitude by gender. In the same vein, Intaganok et al. (2008); Abedalaziz, Jamaluddin and Leng (2013) and Onasanya, Shehu, Oduwaye, and Shehu (2010) reached similar conclusions that gender plays no insignificant role in determining attitudes towards ICT. This finding however contradicts the findings of other researchers (Ainley \& Enger, 2007; Papaioannou \& Charalambous, 2011) who concluded that differences in attitude towards ICT exist in favour of males. It is 
Faculty attitude and use of ICT in instructional delivery in tertiary institutions in a developing nation

noteworthy that females in the institutions studied do not lag behind their male counterparts in any way, especially qualification wise.

The type of institution was discovered to have no influence on the attitudes of faculty members towards ICT. This finding goes a long way to show that lecturers in all the tertiary institutions in Imo state have come to the full realization of the importance of ICT in the $21^{\text {st }}$ century classroom hence all show a positive attitude towards its application in instruction irrespective of the type of tertiary institution they teach. Though researchers report that University lecturers and those of the polytechnics are more competent in the use of ICT than their college of education counterparts (Egomo, Enyi, \& Tah, 2012), the findings of this study tend to suggest that such a gap may no longer be there.

A positive correlation found between attitude towards ICT and ICT use in teaching and learning is in agreement and supported by some scholars (Albrini, 2006; Al-Zaidiyeen, Mei, \& Fook, 2010; Huang \& Liaw, 2005; Sang et al., 2010; Şahin-Kizil, 2011). Thus, the teachers' attitudes to ICT plays a significant role on his or her acceptance of technology in the classroom as well as determines the integration of same in the teaching and learning environment. A more positive attitude towards ICT implies a higher level of utilization in instructional delivery, whereas a negative attitude will translate to minimal use in instruction.

\subsection{Implications}

The low level of ICT usage in teaching by faculty members in tertiary institutions in the state is not a healthy development for educational growth and competitiveness in the present $21^{\text {st }}$ century. This condition denies the tertiary education system of the full benefits of the use of ICT in instruction. The learners on their part will find it difficult to use ICT in their learning and future work places especially the pre-service teachers. This may lead to low information literacy thus placing them in a disadvantaged situation to compete favourably with their peers from other tertiary institutions where ICT has fully been integrated into the learning environment. On the part of the lecturers, collaboration with colleagues outside their institutions for publication and knowledge sharing will be at low level. The positive attitude of the faculty members towards ICT use for instruction and the absence of difference in attitude by gender are of great value to the system. The implication is that despite the low use of ICT, the faculty both male and female are favourably disposed to ICT use in instruction hence with adequate provision of relevant infrastructure and training, the use level will increase. This is against the backdrop that there is a significant positive correlation between attitude and utilization.

\subsection{Recommendations}

The researchers recommend adequate equipment of all the tertiary institutions in the state most especially the state owned institution in terms of the requisite ICT resources needed for effective instructional delivery. Constant training and retraining of the faculty members on instructional application of ICTs rather than general training on ICT is recommended if meaningful use is to be made of ICT in the curriculum. The provision of resources and training of faculty on how to use ICT for instructional purposes will play a motivational role to boost their attitude which invariably will lead to more effective utilization in instructional delivery.

\section{Conclusion}

The researchers conclude this study by stating that there is the need to improve on the level of ICT use in instruction in the tertiary institutions in Imo State if the products of the system must compete favourably with their counterparts from all over the world. This can be done through the provision of adequate ICT resources to act as motivation to faculty to develop positive attitude towards ICT as well as use same in teaching. With a positive correlation between faculty's attitude towards ICT use in education and actual use of ICT in instruction, the need to encourage faculty members to develop a more positive attitude towards ICT use by provision of enabling environment as well as incentives for faculty who are innovative in their use of ICT in teaching. 


\section{References}

Abedalaziz, N., Jamaluddin, S., \& Leng, C. H. (2013). Measuring attitudes toward computer and internet usage among postgraduate students in Malaysia. Turkish Online Journal of Educational Technology-TOJET, 12(2), 200-216.

Aginam, E. (2006, October 18). Nigerian higher education has less 5\% ICT applications. Vanguard Newspapers online. Retrieved from http://www.vanguardngr.com/articles/html

Ainley, J., \& Enger, L. (2007). Student use of, and engagement with, information technology. CEETYA ICT in Schools Taskforce. Australian Council for Educational Research.

Akuegwu, B. A., Ntukidem, E. P., Ntukidem, P. J., \& Jaja, G. (2011). Information and communications technology (ICT) facilities utilization for quality instructional service delivery among university lecturers in Nigeria. Review of Higher Education in Africa, 3(1), 33-53.

Albirini, A. A. (2004). An exploration of the factors associated with the attitudes of high school EFL teachers in Syria toward information and communication technology. Doctoral Dissertation, The Ohio State University, Ohio.

Albirini, A. A. (2006). Teacher's attitudes toward information and communication technologies: The case of Syrian EFL teachers. Journal of Computers and Education, 47, 373-398. http://dx.doi.org/10.1016/j.compedu.2004.10.013

Al-Zaidiyeen, N. J., Mei, L. L., \& Fook, F. S. (2010). Teachers' attitudes and levels of technology use in classrooms: The case of Jordan schools. International Education Studies, 3(2), 211-218. http://dx.doi.org/10.5539/ies.v3n2p211

Balanskat, A., Blamire, R., \& Kefala, S. (2006). The ICT impact report. European Schoolnet. Retrieved from http://colccti.colfinder.org/sites/default/files/ict_impact_report_0.pdf

Bamigboye, O. B., Bankole, O. M., Ajiboye, B. A., \& George, A. E. (2013). Teachers' attitude and competence towards the use of ICT resources: A case study of University of Agriculture lecturers, Abeokuta, Ogun State, Nigeria. The Information Manager 13(1\&2), 10-15.

Becta (2008). Technology and school improvement: reducing social inequity with technology? Retrieved from http://partners.becta.org.uk/index.php?section=rh\&catcode=_re_rp_02\&rid=14541

DCSF. (2008). All parents to get regular online reports on their children's progress. Retrieved from http://www.dcsf.gov.uk/pns/DisplayPN.cgi?pn_id=2008_0006

Dogan, M. (2010). Primary trainee teachers' attitudes to and use of computer and technology in mathematics: The case of Turkey. Educational Research and Review, 5(11), 690-702.

Egomo, J. E., Enyi, B. I., \& Tah, M. M. (2012). Availability and utilization of ICT tools for effective instructional delivery in tertiary institutions in Cross River State, Nigeria. Global Advanced Research Journal of Educational Research and Review, 1(8), 190-195.

Elsadaani, M. (2012). Teaching staff' attitude toward ICT: Is gender a factor? International Women Online Journal of Distance Education, 1(2), 21-30.

Fishbein, .M. A. (1967). Attitude and the prediction of behavior. In M. Fishbein (Ed.), Readings in attitude theory and measurement (pp. 477-492). New York: Wiley.

Hermans, R., Tondeur, J., van Braak, J., \& Valcke, M. (2008). The impact of primary school teachers' educational beliefs on the classroom use of computers. Computers \& Education, 51, 1499-1509. http://dx.doi.org/10.1016/j.compedu.2008.02.001

Hew, K. F., \& Brush, T. (2007). Integrating technology into K-12 teaching and learning: Current knowledge gaps and recommendations for future research. Educational Technology Research and Development, 55(3), 223-252. http://dx.doi.org/10.1007/s11423-006-9022-5

Higgins, S. (2003). Does ICT improve learning and teaching in schools? A professional user review of the UK research undertaken for the British educational research association. Southwell: British Educational Research Association.

Huang H. M., \& Liaw, S. S. (2005). Exploring users' attitudes and intentions toward the web as a survey tool. Computers in Human Behavior, 21, 729-743. http://dx.doi.org/10.1016/j.chb.2004.02.020 
Faculty attitude and use of ICT in instructional delivery in tertiary institutions in a developing nation

Intaganok, P., Waterworth, P. G., Andsavachulamanee, T., Grasaresom, G., \& Homkome, U. (2008). Attitudes of staff to information and communication technologies in a provincial University in Thailand. EJISDC: The Electronic Journal on Information Systems in Developing Countries, 33(3), 1-14.

Keengwe, J., Onchwari, G., \& Wachira, P. (2008). Computer technology integration and student learning: Barriers and promise. Journal of Science Education and Technology, 17(6), 560-565. http://dx.doi.org/10.1007/s10956-008-9123-5

McGregor, E., \& Bazi, F. (2001). Gender mainstreaming in science and technology. United Kingdom: Commonwealth Press Office. http://dx.doi.org/10.14217/9781848597327-en

Meijer, J., van Eck, E., \& Felix, C. (2008). Leren met meer effect: Rapportage van het onderzoek [Learning with more effect: report of the research]. Amsterdam: SCO Kohnstamm Instituut.

Modebelu, M. N., \& Azu, J. O. (2014). Academic staff challenges to effective utilization of information and communication technology (ICT) in teaching/learning of agricultural education. International Letters of Social and Humanistic Sciences, 13, 88-96.

Nigeria, F. R. (2008). National policy on education. Yaba, Lagos: Nigeria Education Research and Development Council (NERDC) Press.

Nnabugwu, F. (2012, March 31). 3 scores above 300 as JAMB release results. Vanguard Newspapers online. Retrieved from http://www.vanguardngr.com/2012/03/only-3-score-over-300-as-jamb-releases-results/

Ochoyi, U. I., \& Ukwumonu, A. J. (2008). Integration of ICT in secondary school curriculum in Nigeria: Problems and prospects. In the 49th Annual STAN conference proceeding on curriculum development in Science, Technology and Mathematics (STM) Education (pp. 207-211).Yenagoa: HEBN Publishers.

Okon, A., \& Jacob, E. (2002). Use of information technology by academic in selected universities in Nigeria. Global Journal of Mathematics Science, 2(1), 57-63.

Oliver, R. (2006). Exploring a technology-facilitated solution to cater for advanced students in large undergraduate classes. Journal of Computer Assisted Learning, 22(1), 1-12. http://dx.doi.org/10.1111/j.1365-2729.2006.00155.x

Onasanya, S. A., Shehu, R. A., Oduwaye, R. O., \& Shehu, L. A. (2010). Higher instructions lecturers' attitudes towards integration of ICT into technology and research in Nigeria. Research Journal of Information Technology, 2, 1-10. http://dx.doi.org/10.3923/rjit.2010.1.10

Onwuagboke, B. B. C., Singh, T. K. R., \& Onwuagboke, J. N. (2014). Availability, gender and teaching experience: Determinants of ICT utilization in teaching in rural secondary schools in south eastern Nigeria. The International Journal of Science and Technoledge, 2(5), 410- 416.

Papaioannou, P., \& Charalambous, K. (2011). Principals' attitudes toward ict and their perceptions about the factors that facilitate or inhibit ICT integration in primary schools of Cyprus. Journal of Information Technology Education, 10, 333-347.

Pelgrum, W. J. (2001). Obstacles to the integration of ICT in education: results from a worldwide educational assessment. Computers \& education, 37(2), 163-178. http://dx.doi.org/10.1016/S0360-1315(01)00045-8

Şahin-Kizil, A. (2011). EFL teachers' attitudes towards information and communication technologies (ICT). In Proceedings of the 5th International Computer \& Instructional Technologies Symposium, Firat University, Laziğ Turkey.

Sang, G. Y., Valcke M., van Braak, J., \& Tondeur, J. (2010). Student teachers' thinking processes and ICT integration: Predictors of prospective teaching behaviors with educational technology. Computers \& Education, 54, 103-112. http://dx.doi.org/10.1016/j.compedu.2009.07.010

The Partnership for Higher Education in Africa. (2007). Securing the linchpin: ICT for teaching, learning and research. Retrieved from http://www.foundation-partnership.org/linchpin/index.php

Uka, S. (2014, October 27). NCC donates computers to schools, others. Punch Newspapers online. Retrieved from http://www.punchng.com/business/technology/ncc-donates-computers-to-schools-others/

Umeh, A. E., \& Okonkwo, C. O. (2014). An assessment of the use of technological materials by students to study Social Studies in Niger State College of education Minna. Developing Country Studies, 4(10), 1-6.

van Braak, J., Tondeur, J., \& Valcke, M. (2004). Explaining different types of computer use among primary 
Onwuagboke, B. B. C., \& Singh, T. K. R.

schoolteachers. European Journal of Psychology of Education, 19, 407-422.

http://dx.doi.org/10.1007/BF03173218

Yusuf, M. O. \& Balogun, M. R. (2011). Student-teachers' competence and attitude towards information and communication technology: A case study in a Nigerian university. Contemporary Educational Technology, 2(1), 18-36.

Ziden, A. A., Ismail, I., Spian, R., \& Kumutha, K. (2011). The effects of ICT use in teaching and learning on students' achievement in science subject in a primary school in Malaysia. Malaysia Journal of Distance Education, 13(2), 19-32. 